\title{
CZY ISTNIEJE POTRZEBA PRZYWRÓCENIA INSTYTUCJI PIERWSZEŃSTWA $Z$ WYSTAWIENIA NA KRAJOWEJ WYSTAWIE PUBLICZNEJ W POLSKIM PRAWIE WŁASNOŚCI PRZEMYSŁOWEJ?
}

\section{Uwagi ogólne}

Celem niniejszego artykułu jest odpowiedź na pytanie, czy możliwe i uzasadnione jest przywrócenie w Ustawie z dnia 30 czerwca 2000 r. Prawo własności przemysłowej ${ }^{3}$ instytucji pierwszeństwa $\mathrm{z}$ wystawienia (zwanego też pierwszeństwem wystawowym lub pierwszeństwem wystawienia ${ }^{4}$ ) odnoszącego się do publicznych wystaw organizowanych w Polsce w odniesieniu do wzorów użytkowych, wzorów przemysłowych i znaków towarowych? Instytucja pierwszeństwa z wystawienia na publicznych wystawach krajowych znajdowała się w polskim systemie prawa własności przemysłowej do dnia 31 października 2007 r. Jednakże w wyniku przeprowadzonej nowelizacji przepisy jej dotyczące zostały uchylone. ${ }^{5}$ Obecnie polski ustawodawca nie przewiduje możliwości powołania się na pierwszeństwo z wystawienia w przypadku wystawienia dóbr niematerialnych na wystawach publicznych organizowanych w Polsce. ${ }^{6}$ Wydaje się, że usunięcia z p.w.p. instytucji pierwszeństwa $\mathrm{z}$ wystawienia na publicznych wystawach krajowych w odniesieniu do wzo-

\footnotetext{
1 Profesor zwyczajny, doktor habilitowany, Katedra Prawa Cywilnego, Handlowego i Ubezpieczeniowego Uniwersytetu im. Adama Mickiewicza w Poznaniu.

2 Doktor nauk prawnych, Katedra Prawa Europejskiego Uniwersytetu im. Adama Mickiewicza w Poznaniu.

Tekst jedn. Dz.U. z 2013 r. poz. 1410, dalej jako p.w.p.

Zob. R. Skubisz, Pierwszeństwo do uzyskania patentu, Warszawa 1982, s. 129-147.

Ustawa o zmianie ustawy - Prawo własności przemysłowej z dnia 29 czerwca 2007 r. (Dz.U. Nr 136, poz. 958). Ustawę ogłoszono 31 lipca 2007 r. i weszła w życie po 3 miesiącach od jej ogłoszenia.

$6 \quad$ Jak wskazuje się w literaturze przedmiotu w wyniku przeprowadzonej nowelizacji przepisów o pierwszeństwie z wystawienia Prezes Urzędu Patentowego RP utracił kompetencję do wskazywania w formie obwieszczenia w Dzienniku Urzędowym RP „Monitor Polski” wystaw publicznych w Polsce, na których wystawienie prowadzi do nabycia pierwszeństwa. Zob. R. Skubisz, (w:) R. Skubisz (red.), System prawa prywatnego, tom 14 A, Prawo własności przemysłowej, Warszawa 2012, s. 464, nb. 76.
} 
rów użytkowych, wzorów przemysłowych i znaków towarowych dokonano zbyt pospiesznie.

\section{Instytucja pierwszeństwa w ogólności}

Wyłączność przyznawana przedsiębiorcom do korzystania z określonych dóbr niematerialnych przez ich rejestrację w Urzędzie Patentowym zakłada, że prawa takie są przyznawane zgłaszającemu na jego wniosek. Jest oczywiste, że do tego samego wzoru czy znaku mogą zostać zgłoszone kolidujące wnioski o rejestrację. $\mathrm{W}$ takim przypadku rozstrzygnięcie kolizji następuje według zasady pierwszeństwa. ${ }^{7} \mathrm{~W}$ literaturze przedmiotu słusznie wskazuje się, że instytucja pierwszeństwa to zespół norm prawnych regulujących stosunki powstające w wyniku dokonywania i zgłaszania w Urzędzie Patentowym takich samych dóbr niematerialnych przez różne osoby niezależenie od siebie. Celem tych norm jest wyłonienie spośród kilku uprawnionych jednej osoby z najlepszym pierwszeństwem, której zostanie przyznane prawo wyłączne. ${ }^{8}$

W Polsce pierwszeństwo powstaje z reguły z chwilą dokonania zgłoszenia w UP (zob. art. 13 p.w.p. i art. 123 p.w.p.). Decydująca będzie tu data zgłoszenia stwierdzona przez UP. Jest to tzw. pierwszeństwo według daty zgłoszenia.

Pierwszym wyjątkiem od zasady, że pierwszeństwo oznacza się według daty zgłoszenia w UP jest instytucja pierwszeństwa konwencyjnego (art. 14 p.w.p. i art. 124 p.w.p.). W takim przypadku pierwszeństwo przysługuje nie według daty zgłoszenia w polskim UP, a według daty pierwszego prawidłowego zgłoszenia we wskazanym Państwie, jeżeli od tej daty zgłoszenie zostanie dokonane w UP w okresie 12 miesięcy w przypadku wynalazków i wzorów użytkowych, 6 miesięcy w przypadku wzorów przemysłowych i znaków towarowych.

Drugim wyjątkiem jest instytucja pierwszeństwa według daty wystawienia dobra niematerialnego w Polsce lub za granicą na wystawie międzynarodowej oficjalnej lub oficjalnie uznanej, jeżeli zgłoszenie w UP zostanie dokonane w ciągu 6 miesięcy od daty wystawienia (art. 15 p.w.p. i art. 125 p.w.p.).

W konsekwencji nie zawsze osoba, która pierwsza zgłosiła swoje dobro niematerialne w UP do rejestracji (pierwszeństwo według daty zgłoszenia) uzyska prawo wyłączne. Może się bowiem okazać, że ma pierwszeństwo „gorsze” niż inna osoba, która takie samo dobro niematerialne zgłosiła już wcześniej w innym państwie lub wystawiła na określonej w przepisach wystawie międzynarodowej (pierwszeństwo

7 Zob. więcej R. Skubisz, Problem zgłoszeń z równym pierwszeństwem, „Zeszyty Naukowe Uniwersytetu Jagiellońskiego, Prace z Wynalazczości i Ochrony Własności Intelektualnej” 1978, z. 18, s. 67-82. I choć artykuł dotyczy wynalazków rozważania aktualne pozostają także w odniesieniu do innych dóbr niematerialnych. Zob. też R. Skubisz, Pierwszeństwo do uzyskania patentu, Warszawa 1982.

8 Zob. więcej: R. Skubisz, Pierwszeństwo do uzyskania patentu, (w:) J. Szwaja i R. Szajkowski (red.), System prawa własności intelektualnej, tom III, Prawo wynalazcze, Wrocław, Warszawa, Kraków, Gdańsk, Łódź 1990, s. 145 . 
z wystawienia). Prawo wyłączne zostanie w takim przypadku przyznane osobie z lepszym pierwszeństwem. W chwili obecnej prawo pierwszeństwa nie przysługuje w przypadku wystawy o charakterze krajowym lub wystawy międzynarodowej oficjalnie nie uznawanej.

\section{Pierwszeństwo z wystawienia w p.w.p.}

W Polsce regulacje dotyczące instytucji pierwszeństwa z wystawienia na wystawach międzynarodowych oficjalnych lub oficjalnie uznanych znajdują się w art. 15 p.w.p. (w odniesieniu do wynalazku, wzoru użytkowego i wzoru przemysłowego) i w art. 125 p.w.p. (w odniesieniu do znaku towarowego). Przepisy te mają swoją podstawę w art. 11 Konwencji paryskiej o ochronie własności przemysłowej z dnia 20 marca 1883 r., ${ }^{9}$ dalej zwanej Konwencją paryską. Zgodnie z Konwencją paryską państwa związkowe, ${ }^{10} \mathrm{~W}$ tym Polska, muszą zapewnić przyznanie ochrony tymczasowej wynalazkom nadającym się do opatentowania, wzorom użytkowym, wzorom przemysłowym, jak również znakom towarowym umieszczonym na produktach, które będą wystawione na wystawach międzynarodowych oficjalnych lub oficjalnie uznanych, urządzanych na terytorium jednego $\mathrm{z}$ państw. ${ }^{11} \mathrm{~W}$ literaturze przedmiotu nie kwestionowano zgodności przyjętych w art. 15 i art. 125 p.w.p. rozwiązań (w brzmieniu sprzed i po nowelizacji) z Konwencją paryską. ${ }^{12}$

Obecnie art. 15 p.w.p. stanowi, że: „Pierwszeństwo do uzyskania patentu, prawa ochronnego albo prawa $\mathrm{z}$ rejestracji oznacza się, na zasadach określonych w umowach międzynarodowych, według daty wystawienia wynalazku, wzoru użytkowego albo wzoru przemysłowego w Polsce lub za granicą, na wystawie międzynarodowej oficjalnej lub oficjalnie uznanej, jeżeli zgłoszenie w Urzędzie Patentowym tego wynalazku, wzoru użytkowego albo wzoru przemysłowego dokonane zostanie w okresie 6 miesięcy od tej daty".

Art. 125 p.w.p. dotyczy znaków towarowych, a jego treść jest tożsama z treścią art. 15 p.w.p.

Jak można zauważyć przytoczone przepisy regulują co prawda kwestie związane z pierwszeństwem z wystawienia, jednakże na pierwszeństwo z wystawienia-

Dz.U. z 1975 r. Nr 9, poz. 51. Art. 11 Konwencji paryskiej stanowi, że „1. Państwa będące członkami Związku udzielą, zgodnie ze swym ustawodawstwem wewnętrznym, ochrony tymczasowej wynalazkom nadającym się do opatentowania, wzorom użytkowym, wzorom przemysłowym, jak również znakom towarowym umieszczonym na produktach, które będą wystawione na wystawach międzynarodowych oficjalnych lub oficjalnie uznanych, urządzanych na terytorium jednego z nich. 2. Ochrona tymczasowa nie przedłuży terminów przewidzianych w artykule 4. Jeżeli na prawo pierwszeństwa powołano się później, organ administracji każdego Państwa będzie mógł liczyć bieg terminu od daty wprowadzenia produktu na wystawę. 3. Każde Państwo będzie mogło żądać, dla stwierdzenia tożsamości przedmiotu wystawianego i daty wprowadzenia, dowodów, jakie uzna za konieczne".

10 Związek tworzą państwa należące do Konwencji paryskiej. Polska należy do związku do $1919 \mathrm{r}$.

11 Szczegółowo na temat art. 11 Konwencji paryskiej i możliwych modelach „tymczasowej ochrony” M. du Vall, Prawo patentowe, Warszawa 2008, s. 67-71, a także R. Skubisz, Pierwszeństwo..., op. cit., s. 131-133.

12 Więcej: M. du Vall, Uwagi do art. 11 Konwencji paryskiej, (w:) A. Adamczak, A. Szewc (red.), Konwencja paryska o ochronie własności przemysłowej. Komentarz, Warszawa 2008, s. 347-352. 
można powołać się tylko i wyłącznie w przypadku wystawienie dóbr niematerialnych na wystawach międzynarodowych oficjalnych i oficjalnie uznanych.

W literaturze przedmiotu wskazuje się, ,że wystawą oficjalną jest wystawa organizowana i zarządzana przez państwo (tzn. jego rząd) lub inną władzę publiczną, za wystawę oficjalnie uznaną uznaje się natomiast wystawę organizowaną i zarządzaną przez organizację, która uzyskała formalną autoryzację ze strony państwa". ${ }^{13}$

Z kolei definicję pojęcia ,wystawa międzynarodowa” można znaleźć w Konwencji o wystawach międzynarodowych, podpisanej w Paryżu w dniu 22 listopada 1928 r. (dalej zwana Konwencją o wystawach międzynarodowych ${ }^{14}$ ).

Zgodnie z Konwencją o wystawach międzynarodowych „,wystawa” to ,ppokaz, który, niezależnie od nazwy, ma cel poznawczy poprzez ukazanie przeglądu środków, jakimi dysponuje człowiek dla zaspokojenia potrzeb cywilizacji oraz postępu osiągniętego w jednej lub w kilku dziedzinach działalności ludzkiej albo ich perspektyw na przyszłość" i w którym uczestniczy więcej niż jedno państwo (zob. art. 1 Konwencji o wystawach międzynarodowych). Dodać trzeba, że Konwencja o wystawach międzynarodowych nie obejmuje swym zakresem wystaw międzynarodowych krótszych niż trzy tygodnie, wystaw sztuk pięknych i wystaw o charakterze ściśle handlowym (zob. art. 2 Konwencji o wystawach). Tylko i wyłącznie wystawienie na takiej wystawie międzynarodowej da możliwość powołania się na pierwszeństwo z wystawienia. ${ }^{15}$ Wystawienie na wszelkich innych wystawach nie będzie dawało takiej możliwości.

Jak zauważają niektórzy autorzy ${ }^{16}$ ustawodawca polski nie odsyła w art. 15 p.w.p. i w art. 125 p.w.p. wyraźnie do Konwencji o wystawach międzynarodowych. Pojawiła się tym samym propozycja, by pojęcie ,wystawa międzynarodowa oficjalna lub oficjalnie uznana" w p.w.p., rozumieć w sposób autonomiczny i nie ograniczać go do wystaw w rozumieniu Konwencji o wystawach międzynarodowych. Sugeruje się zatem, że „,możliwe jest uznanie za oficjalne także takich wystaw, które nie spełniają wymogów z Konwencji o wystawach międzynarodowych". ${ }^{17}$ Takie rozumowanie może jednak praktycznie prowadzić do negatywnych konsekwencji dla uprawnionego, gdyż całe ryzyko odmowy uznania wystawy międzynarodowej za oficjalną lub oficjalnie uznaną ponosić będzie uprawniony powołujący się na pierwszeństwo z wystawienia. Niebezpieczeństwo jest tym bardziej uzasadnione, że obecnie nie ma obowiązku informowania w Polsce, które wystawy uznaje się za oficjalne i oficjalnie uznane w świetle art. 15 p.w.p. i art. 125 p.w.p. Tym samym uzasad-

Tak M. du Vall, Prawo patentowe, op. cit., s. 70

Dz.U. z 1994 r. Nr 56, poz. 232.

Zob. też A. Szewc, G. Jyż, Prawo własności przemysłowej, wyd. 2, Warszawa 2011, s. 168-169.

P. Kostański, Uwagi do art. 15 p.w.p., Nb 7, a także M. Andrzejewski, Uwagi do art. 125 p.w.p., Nb 2, (w:) P. Kostański (red.), Prawo własności przemysłowej Komentarz, wyd. 2., Warszawa 2014, też M. du Vall, Uwagi do art. 11 Konwencji paryskiej, s. 352, Nb. 6, M. du Vall, Prawo patwentowe, s. 69-70, Z. Miklasiński, Prawo własności przemysłowej. Komentarz, Warszawa 2001, s. 42.

Ibidem. 
nionym jest stanowisko M. du Vall, który uważa, że ,wymogi stawiane wystawom na gruncie konwencji z 1928 [Konwencji o wystawach międzynarodowych - przyp. J i M. Kępińscy] są tak surowe, że bez obawy popełnienia błędu można przyjąć, iż każda wystawa zorganizowania zgodnie z przepisami tej konwencji będzie w którymkolwiek kraju Związku Paryskiego uznana za wystawę międzynarodową oficjalną lub oficjalnie uznaną w rozumieniu art. 11 ust. 1 konwencji paryskiej”.

Tym samym, mimo iż zdania są podzielne, to najpewniejsze jednak jest założenie, że umową międzynarodową, o której mowa w przepisie jest Konwencja o wystawach międzynarodowych. ${ }^{18}$

Podsumowując należy podkreślić, że w Polsce obecnie instytucja pierwszeństwa $\mathrm{z}$ wystawienia ma praktycznie bardzo małe znaczenie i znajdzie zastosowanie wyjątkowo. Stąd w pełni należy podzielić pogląd przedstawiany w literaturze przedmiotu, ${ }^{19}$ że przedsiębiorca wystawiając w Polsce wynalazek, wzór użytkowy, wzór przemysłowy lub towary czy świadcząc usługi oznaczone znakiem towarowym powinien wcześniej dokonać ich zgłoszenia w Urzędzie Patentowym lub Urzędzie Harmonizacji Rynku Wewnętrznego.

\section{Instytucja pierwszeństwa z wystawienia w p.w.p. przed nowelizacją}

Art. 15 i 125 p.w.p. w wyniku wspominanej nowelizacji z 2007 r. uległy zmianie. Bowiem do dnia 31 października 2007 r. w p.w.p. przewidziane było pierwszeństwo wystawowe do uzyskania patentu, prawa ochronnego albo prawa z rejestracji także w przypadku wystawienia wynalazku, wzoru użytkowego albo wzoru przemysłowego na innej niż określona w art. 15 ust. 1 p.w.p. (art. 15 ust. 1 p.w.p. dotyczył wystawy międzynarodowej oficjalnie lub oficjalnie uznanej) wystawie publicznej w Polsce, wskazanej przez Prezesa Urzędu Patentowego w formie obwieszczenia w Dzienniku Urzędowym Rzeczypospolitej Polskiej „,Monitor Polski”, ${ }^{20}$

Art. 15 p.w.p. (a także art. 125 w odniesieniu do znaków towarowych) przed nowelizacją miał następując brzmienie :

1. Pierwszeństwo do uzyskania patentu, prawa ochronnego albo prawa z rejestracji oznacza się, na zasadach określonych w umowach międzynarodowych, według daty wystawienia wynalazku, wzoru użytkowego albo wzoru

18 Zob. A. Nowicka, (w:) U. Promińska (red.), Prawo własności przemysłowej, Warszawa 2005, s. 75; R. Skubisz, (w:) System prawa prywatnego..., op. cit., s. 465, Nb. 77, a także A. Szewc, G. Jyż, Prawo własności przemysłowej, op. cit., s. 168.

19 Zob. R. Skubisz, (w:) System prawa prywatnego..., op. cit., s. 465, Nb. 78, a także P. Kostański, Uwagi do art. 15 p.w.p..., op. cit., Nb. 10.

20 Zob. np. Obwieszczenie Prezesa Urzędu Patentowego Rzeczypospolitej Polskiej o wskazaniu wystaw publicznych dających pierwszeństwo do uzyskania patentu, prawa ochronnego albo prawa z rejestracji, w przypadku wystawienia na nich wynalazku, wzoru użytkowego, wzoru przemysłowego lub towaru oznaczonego znakiem towarowym z dnia 5 października 2007 r. (M.P. Nr 74, poz. 801). 
przemysłowego w Polsce lub za granicą, na wystawie międzynarodowej oficjalnej lub oficjalnie uznanej, jeżeli zgłoszenie w Urzędzie Patentowym tego wynalazku, wzoru użytkowego albo wzoru przemysłowego dokonane zostanie w okresie 6 miesięcy od tej daty.

2. Pierwszeństwo do uzyskania patentu, prawa ochronnego albo prawa z rejestracji przysługuje także, na zasadach określonych w ust. 1, w przypadku wystawienia wynalazku, wzoru użytkowego albo wzoru przemysłowego na innej niż określona w ust. 1 wystawie publicznej w Polsce, wskazanej przez Prezesa Urzędu Patentowego w formie obwieszczenia w Dzienniku Urzędowym Rzeczypospolitej Polskiej „Monitor Polski”.

3. Wskazanie wystawy, o którym mowa w ust. 2, może dotyczyć tylko imprezy dającej rękojmię jej wiarygodności, w szczególności jeżeli cieszy się ona ustaloną renomą, ma długoletnią tradycję bądź organizowana jest przez uznaną jednostkę zajmującą się zawodowo organizacją podobnych wystaw.

4. $\mathrm{Z}$ zachowaniem warunków określonych w ust. 3, z inicjatywą wskazania wystawy publicznej w Polsce jako dającej pierwszeństwo, o którym mowa w ust. 2, może także wystąpić właściwy minister lub wojewoda.

W wyniku nowelizacji art. 15 ust. 2, 3 i 4 p.w.p. i art. 125 ust. 2, 3 i 4 p.w.p. zostały uchylone.

Zauważyć trzeba, że początkowo w projekcie nowelizacji przedstawionej w druku sejmowym nr $882^{21}$ nie przewidywano zmiany art. 15 p.w.p. i art. 125 p.w.p. Propozycja takich zmian pojawiła się dopiero w druku sejmowym nr $1176,{ }^{22}$ w którym w punkcie 4 i 28 przewidziano, że w art. 15 p.w.p. uchyla się ust. 2-4 (zob. s. 2 druku 1176), a w art. 125 p.w.p. uchyla się ust. 2-4 (zob. s. 7 druku 1176). W uzasadnieniu projektu przedstawionego w druku 1176 (i kolejnych drukach np. 1176A, 1858, 1881) nie ma żadnego wyjaśnienia, dlaczego wskazane ustępy 2-4 art. 15 p.w.p. i ustępy 2-4 art. 125 p.w.p. zostały uchylone. ${ }^{23}$

Jedyną wskazówką dotyczącą wprowadzonych zmian może być komunikat umieszczony na stronie internetowej Urzędu Patentowego, ${ }^{24}$ w którym Urząd wska-

Dostępny na stronie Sejmu w archiwum Sejmu V kadencji - http://orka.sejm.gov.pl/Druki5ka.nsf/0/6DD789357CB40779C12571D20050D02C?OpenDocument (data dostępu: 14.09.2015 r.).

22 Dostępny na stronie Sejmu w archiwum Sejmu $V$ kadencji - http://orka.sejm.gov.pl/Druki5ka.nsf/0/A9F5750D087A4FABC125723E0046700D?OpenDocument (data dostępu: 14.09.2015 r.).

23 Kwestia ta nie była ani przedmiotem rozważań Biura Analiz Sejmowych (zob. Opinia prawna z dnia 29 stycznia 2007 r. Ocena zgodności z konstytucją zmian do ustawy prawo własności przemysłowej zawartych w druku sejmowym nr 1176-A punkt 2-4. (dostępna na stronie: http://orka.sejm.gov.pl/proc5.nsf/opisy/882.htm , data dostępu: 14.09.2015 r.), ani żadnej dyskusji podczas procesu legislacyjnego (Zob. zapis przebiegu prac legislacyjnych http://orka.sejm.gov.pl/proc5.nsf/opisy/882.htm , data dostępu: 14.09 .2015 r.).

24 http://www.uprp.pl/pierwszenstwo-z-wystawy/Lead05,743,3619,4,index,pl,text/ (data dostępu: 14.09.2015 r.). Treść komunikatu jest następująca: „Rezygnacja z przyznawania pierwszeństwa z organizowanych w kraju wystaw związana jest z koniecznością przestrzegania przez Polskę wiążących ją porozumień międzynarodowych, w tym Konwencji o wystawach międzynarodowych z dnia 22 listopada 1928 r. (Dz.U. z 1994 r. Nr 56, poz. 232 i 233). Pierwszeństwo przyznawane przez Prezesa Urzędu Patentowego w formie obwieszczenia nie było uznawane w przypadku ubiegania się o patent europejski, jak również przy dokonywaniu zgłoszeń w trybie międzyna- 
zuje, że zmiany te związane są z obowiązkiem przestrzegania przez Polskę porozumień międzynarodowych, w tym Konwencji o wystawach międzynarodowych.

\section{Instytucja pierwszeństwa z wystawienia w pracach nad nowelizacją p.w.p.}

Obecnie trwają prace nad nowelizacją p.w.p. Na stronie internetowej Rządowego Centrum Legislacji można znaleźć informacje na temat prac nad „Projektem założeń projektu ustawy o zmianie ustawy - Prawo własności przemysłowej”. ${ }^{25}$

Jak wynika z tych dokumentów prace nad nowelizacją rozpoczęto w $2012 \mathrm{r}$. z inicjatywy Ministra Gospodarki. Projekt nowelizacji ma realizować przepisy prawa Unii Europejskiej, tzn. „Dyrektywę Parlamentu Europejskiego i Rady z dnia 13 października 1998 r. w sprawie prawnej ochrony wzorów (98/71/WE) (Dz. Urz. UE L. z 28.10.1998 r., nr 289/28), pierwszą Dyrektywę Rady z dnia 21 grudnia 1988 r. mającą na celu zbliżenie ustawodawstw państw członkowskich odnoszących się do znaków towarowych (98/104/EWG), ${ }^{26}$ Dyrektywę 98/44/WE Parlamentu Europejskiego i Rady z dnia 6 lipca 1998 r. o ochronie prawnej wynalazków biotechnologicznych oraz wyroki TS UE C-428/08, C-198/10, C-245/02 i C- 17/06”. Obecnie ukończone zostały prace nad projektem założeń projektu ustawy p.w.p. ${ }^{27}$ Przedstawiona została nowa wersja „Projektu założeń projektu ustawy o zmianie ustawy - Prawo własności przemysłowej” z dnia 19 kwietnia 2013 r., ${ }^{28}$ na podstawie którego przygotowany został „Rządowy projekt ustawy”, który w dniu 13 marca 2015 r. został skierowany do Sejmu (zob. projekt ustawy ${ }^{29}$ ).

rodowym w ramach Układu o współpracy patentowej (PCT). Oznaczało to, iż zgłaszający wystawiając wynalazek na takiej wystawie, ponosił ryzyko, iż Europejski Urząd Patentowy, bądź też urząd patentowy kraju, w którym ubiegano się o ochronę, odmówi udzielenia patentu na zgłoszony wynalazek ze względu na brak nowości. Wobec powyższego, obecnie istnieje jedynie możliwość ubiegania się o pierwszeństwo do uzyskania patentu, prawa ochronnego lub prawa z rejestracji w przypadku wystawienia wynalazku, wzoru użytkowego lub wzoru przemysłowego na wystawie międzynarodowej oficjalnej lub oficjalnie uznanej w rozumieniu ww. Konwencji o wystawach międzynarodowych.

25 Przebieg zapisu prac wraz z przedstawiony projektem założeń na stronie Rządowego Centrum Legislacji: http:// legislacja.rcl.gov.pl/projekt/67441/katalog/67442\# (data dostępu: 14.09.2015 r.).

26 Warto zauważyć, że jest to więc błędne wskazanie Dyrektywy, gdyż Dyrektywa ta w tym momencie już nie obowiązywała. Obecnie obowiązuje bowiem nowa Dyrektywa 2008/95/WE. Zob. też pkt 4.3. Opinii.

27 Prace nad projektem trwają. Projekt „przeszedł” przez fazę konsultacji społecznych (projekt był konsultowany społecznie z : Polską Izbą Rzeczników Patentowych, Stowarzyszeniem Ochrony Własności Przemysłowej, Zrzeszeniem Rzeczników Patentowych Prowadzących Kancelarie, Stowarzyszeniem Polskich Wynalazców Racjonalizatorów, Polskim Związkiem Wynalazców i Racjonalizatorów, Naczelną Organizacją Techniczną - Federacją Stowarzyszeń Naukowo-Technicznych, Polską Konfederacją Pracodawców Prywatnych Lewiatan, Business Centre Club, Pracodawcami RP, Krajową Izbą Gospodarczą oraz Polskim Związkiem Pracodawców Przemysłu Farmaceutycznego.), uzgodnień (uwagi przedstawili: Minister Nauki i Szkolnictwa Wyższego, Prokuratoria Generalna Skarbu Państwa, Minister Finansów. Minister Obrony Narodowej, Rządowe Centrum Legislacji, Ministerstwo Gospodarki, Ministerstwo Rozwoju Regionalnego, Ministerstwo Spraw Wewnętrznych, Minister Rolnictwa i Rozwoju Wsi, Minister Spraw Zagranicznych), dyskutowany był w Stałym Komitecie Rady Ministrów, w Komitecie do spraw Europejskich oraz w Radzie Ministrów.

28 Zgodnie z protokołem ustaleń nr 29/2013 z posiedzenia Rady Ministrów z dnia 16 lipca 2013 r. projekt założeń został przyjęty przez Radę Ministrów.

29 Projekt ustawy jest dostępny na stronie: http://www.sejm.gov.pl/Sejm7.nsf/agent.xsp?symbol=RPL\&Id=RM-10-62-13 (data dostępu: 14.09.2015 r.). Zgodnie z informacjami na stronach sejmowych projekt ma 
Z analizy przedstawionych dokumentów i prac wynika, że w projekcie założeń nie była podnoszona kwestia pierwszeństwa $\mathrm{z}$ wystawienia na publicznych wystawach w Polsce. Nie jest ona w żadnym zakresie ujęta w projekcie ustawy.

\section{Przedmiotowy zakres instytucji pierwszeństwa z wystawienia}

\subsection{Uwagi ogólne}

Rozważania dotyczące przywrócenia instytucji pierwszeństwa $\mathrm{z}$ wystawienia na publicznych wystawach w Polsce powinno ograniczyć się do pierwszeństwa $\mathrm{z}$ wystawienia $\mathrm{w}$ odniesieniu do wzorów użytkowych, wzorów przemysłowych i znaków towarowych. Zgodzić się bowiem należy, że w przypadku wynalazków, w związku z koniecznością przestrzegania przez Polskę porozumień międzynarodowych, ograniczenie możliwości powołania się na pierwszeństwa z wystawienia wynalazku do wystaw międzynarodowych oficjalnych lub oficjalnie uznanych w rozumieniu Konwencji o wystawach międzynarodowych jest uzasadnione. Warto zauważyć, że podobnie zdecydował ustawodawca niemiecki, który już w roku 1980 dopasowując niemieckie prawo patentowe do europejskiego prawa patentowego wykluczył możliwość powoływania się na pierwszeństwo z wystawienia wynalazków na wystawach krajowych. ${ }^{30}$

\subsection{Wzór użytkowy}

Regulacje dotyczące wzorów użytkowych znajdują się w p.w.p. w Dziale III „Wzory użytkowe i prawa ochronne na wzory użytkowe” (zob. art. 94-101 p.w.p.). Ponadto, zgodnie z art. 100 p.w.p. w stosunku do wzorów użytkowych znajdą odpo-

realizować przepisy prawa Unii Europejskiej: „Akt genewski Porozumienia haskiego o międzynarodowej rejestracji wzorów przemysłowych - zmiany w artykułach 117(1)-117(5) ustawy p.w.p., Traktat Singapurski o prawie znaków towarowych - zmiany w artykule 243 ust 2 ustawy p.w.p., Dyrektywa 98/71/WE Parlamentu Europejskiego i Rady z dnia 13 października 1998 r. w sprawie prawnej ochrony wzorów - zmiany w artykule 102 ust. 1 ustawy p.w.p., Dyrektywa 2008/95/WE Parlamentu Europejskiego i Rady z dnia 22 października 2008 r. ws. zbliżenia ustawodawstw państw członkowskich odnoszących się do znaków towarowych - zmiany w artykule 131 ust. 1 pkt 3 ustawy p.w.p., Dyrektywa 98/44/WE Parlamentu Europejskiego i Rady z dnia 6 lipca 1998 r. o ochronie prawnej wynalazków biotechnologicznych - zmiany w artykule 932 ustawy p.w.p., Wyrok TSUE w sprawie C-428/08 (Monsanto Technology) - zmiany w artykule 93 ustawy p.w.p., Wyrok TSUE w sprawie C-198/10 (Cassina) i C-168/09 (Flos) - zmiany w artykule 116 ustawy p.w.p.".

30 Zob. A. Krieger, Das neue deutsche Patentrecht nach der Harmonisierung mit dem europäischen Patentrechte - eine Übersicht, GRUR Int, 1981, s. 273-284. Autor wskazuje, że dopasowanie prawa niemieckiego konieczne było w związku z $\S 4$ ust. 4 Konwencji strasburskiej w sprawie ujednolicenia niektórych pojęć prawa materialnego dotyczącego patentów dla wynalazków z dnia 27 listopada 1963 r., który przewidywał możliwość pierwszeństwa z wystawienie wynalazku na wystawach oficjalnych lub oficjalnie uznanych w rozumieniu Konwencji z 1928 r. o wystawach międzynarodowych. Przepis ten został przejęty do art. 55 Konwencji monachijskiej o patencie europejskim, Konwencja o udzielaniu patentów europejskich (Konwencja o patencie europejskim), sporządzona w Monachium dnia 5 października 1973 r., zmieniona aktem zmieniającym artykuł 63 Konwencji z dnia 17 grudnia 1991 r. oraz decyzjami Rady Administracyjnej Europejskiej Organizacji Patentowej z dnia 21 grudnia 1978 r. 13 grudnia 1994 r. 20 października 1995 r., 5 grudnia 1996 r. oraz 10 grudnia 1998 r. wraz z Protokołami stanowiącymi jej integralną część z dnia 5 października 1973 r. (Dz.U. z 2004 r. Nr 79, poz. 737). 
wiednie zastosowanie także przepisy dotyczące wynalazków. Ustawowa definicja wzoru użytkowego znajduje się w art. 94 p.w.p., zgodnie z którym jest to nowe, użyteczne rozwiązanie o charakterze technicznym, dotyczące kształtu, budowy lub zestawienia przedmiotu o trwałej postaci.

W przypadku wzoru użytkowego na wystawie najistotniejszy jest wymóg posiadania przez wzór użytkowy nowości (art. 94 w zw. z art. 100 i art. 25 p.w.p.). Nowość może utracić rozwiązanie będące wzorem użytkowym przez każde jego udostępnienie do wiadomości publicznej w tym przez jego wystawienie (verba legis art. 25 ust. 2 p.w.p.). A zatem umieszczenie na wystawie przedmiotu wystawionego według rozwiązania będącego wzorem użytkowym pozbawia to rozwiązanie techniczne automatycznie ochrony poprzez rejestrację z braku cechy nowości. Priorytet wystawowy pozwala natomiast zachować ochronę takiego rozwiązania, jeżeli jego zgłoszenie w Urzędzie Patentowym nastąpi w okresie trwania priorytetu. Zatem bez regulacji ustawowej w tej kwestii wystawienie wzorów użytkowych na targach i wystawach $\mathrm{z}$ reguły prowadzi do odmowy ich rejestracji z braku cechy nowości.

$\mathrm{Na}$ poziomie unijnym nie udało się zharmonizować przepisów dotyczących wzorów użytkowych, choć takie próby były podejmowane. Próby takie zakończyły się fiaskiem i od 2002 r. nie podjęto dalszych działań.

Tym samym rozważana kwestia pierwszeństwa $\mathrm{z}$ wystawienia na publicznych wystawach w Polsce odnosi się wyłącznie do polskich wzorów użytkowych.

\subsection{Wzór przemyslowy}

Problematyka wzorów przemysłowych została uregulowana w p.w.p. w dziale IV „Wzory przemysłowe i prawa z rejestracji wzorów przemysłowych”. ${ }^{31}$ Zgodnie z art. 102 ust. 1 p.w.p. wzorem przemysłowym jest nowa i posiadająca indywidualny charakter postać wytworu lub jego części, nadana mu w szczególności przez cechy linii, konturów, kształtów, kolorystykę, strukturę lub materiał wytworu oraz przez jego ornamentację.

Obecne brzmienie przepisów p.w.p. jest implementacją Dyrektywy 98/71/ WE w sprawie prawnej ochrony wzorów, ${ }^{32}$ której celem było zbliżenie przepisów prawnych państw członkowskich dotyczących wzorów przemysłowych. Państwom członkowskim pozostawiono swobodę uregulowania procedury rejestracji, odnowienia i unieważnienia praw dotyczących wzorów oraz skutków unieważnienia. ${ }^{33}$

31 Zastosowanie znajdują także niektóre z przepisów dotyczące wynalazków - zob. art. 118 p.w.p., który odsyła do wskazanych w nim przepisów dotyczących wynalazków.

32 Dyrektywa 98/71/WE Parlamentu Europejskiego i Rady z dnia 13 października 1998 r. w sprawie prawnej ochrony wzorów, Dz.Urz. UE L 289 z dnia 28 października 1998 r., s. 28-35.

33 Dodać należy, że Rozporządzenie 6/2002 (z dnia 12 grudnia 2001 r. w sprawie wzorów wspólnotowych, Dz. Urz. UW L 3 z dnia 5 stycznia 2002 r., s. 1-24) wprowadza na poziomie unijnym, system ochrony wspólnotowych wzorów współistniejący z krajowymi systemami ochrony, lecz w stosunku do nich autonomiczny. Przewiduje on rejestrację wzoru w Urzędzie Harmonizacji Rynku Wewnętrznego (dalej zwany OHIM) w Alicante. Rejestracja wzoru w OHIM umożliwia uzyskanie ochrony we wszystkich krajach Unii Europejskiej. Rejestracja ta nie wyłącza możliwości ochrony wzorów przemysłowych przez przepisy krajowe i dopuszcza ich rejestrację w krajowych urzędach 
Podobnie jak w przypadku wzorów użytkowych wzór przemysłowy, by mógł uzyskać ochronę, musi odznaczać się nowością. Nowość wzoru niweczy jego publiczne udostępnienie następujące między innymi przez jego wystawienie (art. 103 ust. 1 p.w.p.). W związku z tym podobnie jak ma to miejsce w odniesieniu do wzoru użytkowego wystawienie wytworów wytworzonych według wzoru przemysłowego jest zagrożeniem dla jego zdolności rejestracyjnej w Urzędzie Patentowym. Jednakże w odniesieniu do wzoru przemysłowego uzyskanie prawa $\mathrm{z}$ rejestracji wzoru jest łatwiejsze niż wzoru użytkowego, mimo wystawienia wzoru przemysłowego na wystawie, gdyż wzorowi przemysłowemu przysługuje okres łaski (grace period, delai de grace). Oznacza to, że w ciągu 12 miesięcy od ujawnienia wzoru można zgłosić wniosek o jego rejestrację w Urzędzie Patentowym i uzyskać ochronę przed innymi zgłaszającymi taki sam wzór po dacie jego ujawnienie na targach lub wystawach. Jak z tego wynika, ujawnienie wzoru przemysłowego na targach lub wystawach daje aż 12-miesięczny okres na to, aby można było zgłosić ten wzór do ochrony przed wszystkimi, którzy zgłaszają taki sam wzór do ochrony po dacie ujawnienia. $Z$ tego jednakże wynika także, że uzyskanie na targach lub wystawach właściwych zaświadczeń ułatwia proces rejestracji wzoru przemysłowego w Urzędzie Patentowym. Wystawienie bowiem wzoru na oficjalnej wystawie jest w takim przypadku urzędowo poświadczone.

Ponadto wzór przemysłowy ujawniony publicznie na terenie UE jest także chroniony jako niezarejestrowany wzór wspólnotowy przez okres 3 lat od daty jego ujawnienia (art. 11 ust. 1 rozporządzenia 6/2002 w sprawie wzorów wspólnotowych ${ }^{34}$ ). Ochrona takiego wzoru zaczyna płynąc $\mathrm{z}$ chwilą jego publicznego udostępnienia. Tym samym ustalenie daty ujawnienia wzoru na wystawie pozwala na wyznaczenie w pewny sposób okresu ochrony takiego wzoru. Ochrona przysługuje bez żadnych formalności na terenie całej Unii Europejskiej. Chociaż p.w.p. nie zawiera w tej sprawie żadnej wzmianki, ochrona ta następuje także w Polsce, gdyż przepisy rozporządzenia 6/2002 są stosowane w całej UE bezpośrednio.

Tym samym rozważana kwestia pierwszeństwa $\mathrm{z}$ wystawienia na publicznych wystawach w Polsce odnosi się wyłącznie do wzorów przemysłowych rejestrowanych w Polsce.

patentowych lub ich odpowiednikach. W takim wypadku jednak ochrona wzoru obejmuje tylko państwo, w którym rejestracja miała miejsce. notowy wzór niezarejestrowany (Zob. J. Sieńczyło-Chlabicz, Ochrona niezarejestrowanego wzoru wspólnotowego, „Europejski Przegląd Sądowy” 2008, nr 2, s. 10-17; A. Tischner, Niezarejestrowany wzór wspólnotowy, „Przegląd Prawa Handlowego” 2006, nr 7, s. 36-42; J. Kępiński, Wzór przemysłowy i jego ochrona w prawie polskim i wspólnotowym, Warszawa 2010, s. 119-131, V. Sáez, The Unregistered Community Design, „European Intellectual Property Review” 2002, nr 12, s. 585-590). W odróżnieniu od wzoru wspólnotowego (zarejestrowanego) wzór wspólnotowy niezarejestrowany nie musi zostać zarejestrowany, aby uzyskać ochronę, aczkolwiek zakres ochrony jest ograniczony, w porównaniu do wspólnotowego wzoru (zarejestrowanego). p.w.p. nie zawiera w ogóle regulacji dot. wzoru przemysłowego niezarejestrowanego. 


\subsection{Znak towarowy}

Polski system ochrony znaków towarowych uregulowany jest w p.w.p. w tytule III Dział I „Znaki towarowe i prawa ochronne”. Zgodnie z art. 120 ust. 1 p.w.p. znakiem towarowym może być każde oznaczenie, które można przedstawić w sposób graficzny, jeżeli oznaczenie takie nadaje się do odróżnienia towarów jednego przedsiębiorcy od towarów innego przedsiębiorcy.

Przepisy dotyczące znaków towarowych zostały zharmonizowane na mocy pierwszej Dyrektywy Rady 89/104 z dnia 21 grudnia 1988 r. mającej na celu zbliżenie ustawodawstw państw członkowskich odnoszących się do znaków towarowych ${ }^{35}$ która został zastąpiona Dyrektywą Parlamentu Europejskiego i Rady 2008/95/WE z dnia 22 października 2008 r. mającą na celu zbliżenie ustawodawstw państw członkowskich odnoszących się do znaków towarowych. ${ }^{36}$

Polski przedsiębiorca może wybrać krajowy bądź unijny system ochrony znaków. Podstawą przyznania ochrony znaku towarowego jest jego rejestracja w polskim Urzędzie Patentowym lub w OHIM.

W wyniku krajowej rejestracji prawo ochronne na znak towarowy będzie przyznane na terytorium Polski, a w przypadku rejestracji unijnej jednolita ochrona zostanie przyznana na terytorium całej Unii Europejskiej. Oba systemy ochrony współistnieją ze sobą, co może pociągać za sobą różnego rodzaju konsekwencje. Przykładowo jeśli znak wspólnotowy został zarejestrowany, a wcześniej był już zarejestrowany taki sam znak w państwie członkowskim, to znak wspólnotowy będzie mógł być unieważniony. Podobnie jest także w sytuacji odwrotnej. Wcześniejsza unijna rejestracja znaku w OHIM będzie stała na przeszkodzie rejestracji takiego samego znaku w państwach członkowskich UE.

W przeciwieństwie do wzorów użytkowych i wzorów przemysłowych znak towarowy zgłaszany do rejestracji nie musi być nowy. Wystarcza w zasadzie, że taki sam znak nie jest jeszcze zarejestrowany dla takich samych lub podobnych towarów lub usług. Jednakże wystawienie na wystawie lub targach atrakcyjnie oznaczonego towaru może zachęcać konkurentów do naśladowania takiego oznaczenia i jego zgłoszenia w Urzędzie Patentowym w celu ochrony. Przyznanie znakom towarowym

35 Dz. Urz. WE L nr 40 z dnia 11 lutego 1989, s. 1.

36 Dz. Urz. UE L nr 299 z dnia 8 listopada 2008, s. 25. Dyrektywy 89/104 i 2008/95/WE miały na celu tylko i wyłącznie zharmonizowanie systemów krajowych, tak aby ułatwiać przepływ towarów i usług pomiędzy państwami członkowskimi UE. Systemy krajowe państw członkowskich UE, w tym Polski, współistnieją z unijnym systemem ochrony wspólnotowych znaków towarowych. System unijny został ustanowiony Rozporządzeniem Rady (WE) NR 40/94 z dnia 20 grudnia 1993 r. w sprawie wspólnotowego znaku towarowego (Dz. Urz. WE L nr 11 z dnia 15 grudnia 1994 r., s. 1). Rozporządzenie to było nowelizowane i dla zapewnienia jasności i zrozumiałości jego przepisów została sporządzona wersja ujednolicona. Obecnie obowiązuje Rozporządzenie Rady (WE) nr 207/2009 z dnia 26 lutego 2009 r. w sprawie wspólnotowego znaku towarowego (Dz. Urz. UE L nr 78 z dnia 24 marca 2009 r., s. 1). Celem Rozporządzenia było stworzenie jednolitego prawa do znaku wspólnotowego, które rozciąga się na całą Unię Europejską. Zob. Art. 1 ust. 2 Rozporządzenia 207/2009 „Wspólnotowy znak towarowy ma charakter jednolity. Wywołuje on ten sam skutek w całej Wspólnocie: może on być zarejestrowany, zbyty, być przedmiotem zrzeczenia się lub decyzji stwierdzającej wygaśnięcie praw właściciela znaku lub unieważnienie znaku, a jego używanie może być zakazane jedynie w odniesieniu do całej Wspólnoty. Zasadę tę stosuje się, jeżeli niniejsze rozporządzenie nie stanowi inaczej". 
i usługowym prezentowanym na targach i wystawach pierwszeństwa uzyskania rejestracji ułatwia rozstrzygnięcie takich kolizji na rzecz przedsiębiorców wystawiających swoje towary na targach lub wystawach. Podnosi to zatem prestiż targów i wystaw. Przedsiębiorcom ułatwia to dostarczenie Urzędowi Patentowemu dowodu, że wystawiający przedsiębiorca korzysta $\mathrm{z}$ określoną urzędowo datą z pierwszeństwa wystawienia towaru lub usługi oznaczonej znakiem towarowym. Ponadto z reguły będzie to także dowód na to, że znak był używany w sposób rzeczywisty już w tej dacie (art. 169 ust. 1 pkt 1, ust. 4 i ust. 5 p.w.p.).

Niniejsza propozycja wprowadzenia instytucji pierwszeństwa z wystawienia towaru opatrzonego znakiem towarowym na publicznej wystawie w Polsce będzie odnosiła się do znaków towarowych rejestrowanych w Polsce.

\section{Pierwszeństwo z wystawienia w prawie UE i wybranych państw członkowskich}

\subsection{Prawo unijne}

W przypadku wzorów wspólnotowych i wspólnotowych znaków towarowych rozporządzenie 6/2002 i rozporządzenie 207/2009 przewidują pierwszeństwo z wystawienia. Jednakże pierwszeństwo z wystawienia ogranicza się tylko do wystawienia na oficjalnej lub oficjalnie uznanej wystawie międzynarodowej podlegającej warunkom Konwencji o wystawach międzynarodowych podpisanej w Paryżu dnia 22 listopada $1928 \mathrm{r}$.

W przypadku wzoru wspólnotowego (art. 33 rozporządzenia 6/2002), jeżeli zgłaszający zarejestrowany wzór wspólnotowy wystawił wytwory, w których wzór jest zawarty lub zastosowany, podczas oficjalnej lub oficjalnie uznanej wystawy międzynarodowej podlegającej warunkom Konwencji o wystawach międzynarodowych podpisanej w Paryżu dnia 22 listopada 1928 r. i ostatnio zmienionej dnia 30 listopada 1972 r., może on, pod warunkiem dokonania zgłoszenia w terminie sześciu miesięcy od daty pierwszego ujawnienia wytworów, zastrzec prawo pierwszeństwa od tej daty w rozumieniu art. 43. Zgłaszający, który zamierza zastrzec prawo pierwszeństwa zgodnie $\mathrm{z}$ ust. 1, przedstawia dowody, że wystawione towary były wytworzone według wzoru, na warunkach przewidzianych w rozporządzeniu wykonawczym.

Pierwszeństwo $\mathrm{z}$ wystawienia przyznane w państwie członkowskim lub w państwie trzecim nie powoduje przedłużenia terminu pierwszeństwa ustanowionego w art. 41.

Identycznie uregulowano pierwszeństwo z wystawienia w odniesieniu do znaku towarowego. I tak, art. 33 rozporządzenia 207/2009 reguluje, że jeżeli zgłaszający wspólnotowy znak towarowy wystawił towary lub usługi oznaczone zgłaszanym znakiem podczas oficjalnej lub oficjalnie uznanej wystawy międzynarodowej podlegającej warunkom Konwencji o wystawach międzynarodowych podpisanej w Pa- 
ryżu dnia 22 listopada 1928 r. i ostatnio zmienionej dnia 30 listopada 1972 r., może on, pod warunkiem dokonania zgłoszenia w terminie sześciu miesięcy od daty pierwszego wystawienia towarów lub usług oznaczonych zgłaszanym znakiem, zastrzec prawo pierwszeństwa od tej daty w rozumieniu art. 31. Zgłaszający, który zamierza zastrzec prawo pierwszeństwa zgodnie z ust. 1, przedstawia dowody, że wystawione towary lub usługi były oznaczone zgłaszanym znakiem, na warunkach ustanowionych w rozporządzeniu wykonawczym.

W art. 33 ust. 3 rozporządzenia 207/2009 wyraźnie podkreślono, że pierwszeństwo z wystawienia, przyznane w państwie członkowskim lub w państwie trzecim, nie powoduje przedłużenia terminu pierwszeństwa ustanowionego w art. 29. Oznacza to, że data pierwszeństwa z wystawy międzynarodowej jest uznawana za datę dokonania zgłoszenia wspólnotowego znaku towarowego w celu ustalenia, które z kolidujących ewentualnie praw posiadają lepsze pierwszeństwo (art. 31).

Zauważyć należy, jak już zresztą podkreślano wcześniej, że tylko nieliczne wystawy uzyskują status wystawy w rozumieniu Konwencji o wystawach międzynarodowych. Jasnym jest też, co podkreśla się w literaturze niemieckiej, że np. wystawy wskazane w oficjalnym publikatorze przez niemieckie Ministerstwo Sprawiedliwości i Ochrony Konsumenta, które umożliwiają powołanie się na krajowe pierwszeństwo wystawowe, nie należą do tej kategorii wystaw. ${ }^{37}$

Podobnie zaznacza Prezydent Urzędu Harmonizacji Rynku Wewnętrznego w Alicante w komunikacie z dnia 27 stycznia 2003 r. Zgodnie z komunikatem nie można $\mathrm{w}$ przypadku rejestracji wspólnotowej powoływać się na pierwszeństwo z wystawienia na wystawach krajowych, które nie są wystawami w rozumieniu Konwencji o wystawach międzynarodowych (do której odwołuje się art. 44 rozporządzenia 207/2009 i art. 33 rozporządzenia 6/2002). ${ }^{38}$ Jeśli wystawa międzynarodowa korzystająca z przywileju pierwszeństwa będzie miała miejsce, Prezydent OHIM ogłasza o tym w komunikatach. Do tej pory Prezydent OHIM wskazał zaledwie (od 1997 r.) 5 wystaw, na których wystawienie dawało możliwość powołania się na pierwszeństw z wystawienia. ${ }^{39} \mathrm{Nie}$ ulega tym samym wątpliwości, że rola pierwszeństwa z wystawienia w odniesieniu do wspólnotowych wzorów i znaków jest bardzo ograniczona.

37 Zob. G. Eisenführ, D. Schennen, Gemeinschaftsmarkenverordnung, wyd. 2, Köln, Berlin, München 2007, s. 427, Nb. 1.

38 http://oami.europa.eu/en/office/aspects/communications/01-03.htm (data dostępu: 14.09.2015 r.).

39 Komunikaty dostępne są na stronie: https://oami.europa.eu/ohimportal/pl/decisions-and-communications-of-the-president (data dostępu: 14.09.2015 r.). Zob. Communication No 3/97 of the President of the Office of 17.12.1997 - The Oceans, a Heritage for the Future' (22.05 to 30.09. 1998 in Lisbon, Portugal, 'Man, Nature, Technology' (1.06 - 31.10) 2000 in Hanover, Germany, Communication No 1/05 of the President of the Office of 26.01.2005 - The 2005 World Exposition, Aichi, Japan (25.03 to 25.092005 in Nagoya, Japan), Communication No $1 / 08$ of the President of the Office 24.01.2008, The World Exposition 'Water and Sustainable Development' from 14.06-14.10.2008 in Zaragoza, Spain, The World Exposition 'Better City - Better Life' (1.05 - 31.10.2010 in Shanghai, China). 
Warto zwrócić uwagę, że z tych trudności zdają sobie sprawę podmioty związane z branżą targową. Dla przykładu można przywołać stanowisko stowarzyszenia European Major Exhibition Centres Association (EMECA) ${ }^{40} \mathrm{z}$ siedzibą w Brukseli, przedstawione w "EMECA Position Paper, EMECA and the Review of the EU Council Regulation No 6/2002 on Community Design". ${ }^{41}$ Stowarzyszenie postuluje, by wprowadzić możliwość wystawiania certyfikatów pierwszeństwa przez organizatorów targów i wystaw w odniesieniu do wzorów wspólnotowych, które byłyby akceptowane przez OHIM. EMECA podkreśla, że takie certyfikaty wystawiane na targach nie są uwzględnianie przez OHIM. W związku z tym EMECA stoi na stanowisku, że z art. 33 rozporządzenia 6/2002 dotyczącego wspólnotowego wzoru powinno zostać usunięte odwołanie do Konwencji o wystawach międzynarodowych, a zamiast tego powinna być wprowadzona jednolita definicja targów międzynarodowych używana m.in. przez Global Association of the Exhibition Industry. ${ }^{42}$ Pozwoliłoby to na objęcie zakresem art. 33 Rozporządzenia 6/2002 większej liczby wystaw.

Być może, biorąc pod uwagę propozycję stowarzyszenie EMECA można by ewentualnie postulować nie tylko zmianę definicji określenia ,wystawa międzynarodowa" zawartej w rozporządzeniu 6/2002, ale nawet wprowadzenie instytucji pierwszeństwa z wystawienia na publicznych wystawach krajowych. Katalog wystaw byłby publikowany tak jak obecnie, np. w komunikatach Prezydenta OHIM w uzgodnieniu np. z Urzędami Patentowymi lub ich odpowiednikami w państwach członkowskich. Uwaga to pozostaje także aktualna w odniesieniu do wspólnotowych znaków towarowych.

\subsection{Francja}

We Francji ochrona tymczasowa własności przemysłowej na wystawach jest uregulowana w zasadzie poza art. L.611-13 Code de la Propriété Intellectuelle. ${ }^{43}$ Ar-

40 Zob. więcej: http://www.emeca.eu/ (data dostępu: 14.09.2015 r.).

41 EMECA Position Paper, EMECA and the Review of the EU Council Regulation No 6/2002 on Community Design, Niepublikowane.

42 Zob. EMECA Position Paper, EMECA and the Review of the EU Council Regulation No 6/2002 on Community Design, s. 3. Kryteria są następujące, Międzynarodowe Targi muszą spełnić jeden z warunków : a) zagraniczni wystawcy muszą reprezentować co najmniej $10 \%$ całej liczby wystawców lub 2) zagraniczni odwiedzjący muszą stanowić co najmniej $5 \%$ całej liczby odwiedzających (tłumaczenie własne z języka angielskiego) International Trade Fair must fulfil one of these conditions: a) direct foreign Exhibitors representing at least $10 \%$ of the total number of exhibitors; or b) foreign visitors representing at least $5 \%$ of the total number of visitors.

43 Code de la propriété intellectuelle (version consolidée au 22 décembre 2014). Dostępny na http://www.wipo. int/wipolex/en/text.jsp?file_id=359679 (data dostępu: 14.09.2015 r.). Art. 611-13 "Pour l'application de l'article L. 611-11, une divulgation de l'invention n'est pas prise en considération dans les deux cas suivants :-si elle a lieu dans les six mois précédant la date du dépôt de la demande de brevet ;-si elle résulte de la publication, après la date de ce dépôt, d'une demande de brevet antérieure et si, dans l'un ou l'autre cas, elle résulte directement ou indirectement : a) D'un abus évident à l'égard de l'inventeur ou de son prédécesseur en droit ; b) Du fait que l'invention ait été présentée par eux dans une exposition officielle ou officiellement reconnue au sens de la convention révisée concernant les expositions internationales signée à Paris le 22 novembre 1928. Toutefois, dans ce dernier cas, l'exposition de l'invention doit avoir été déclarée lors du dépôt et une justification produite dans les délais et conditions fixés par voie réglementaire". 
tykuł ten jest uzupełniony przez przepisy ustawy z dnia 13 kwietnia 1908 r., ${ }^{44}$ która odnosi się do wystaw międzynarodowych i dekretu z dnia 17 lipca 1908 r., który odnosi się m.in. do wystaw urzędowo uznanych organizowanych we Francji. Przepisy te dotyczą m.in. wzorów przemysłowych i znaków towarowych (ale także wynalazków). Każdy wystawca towarów dotyczących tych praw własności przemysłowej może na żądanie we właściwym urzędzie (prefekturze) otrzymać świadectwo wystawienia (Un Certificat de Garantie). Świadectwo takie daje wystawiającemu taką samą ochronę, jaką daje zgłoszenie do ochrony wzoru przemysłowego lub znaku towarowego w L'office National de la Propriété Industrielle. Ochrona tymczasowa trwa przez okres 12 miesięcy od daty otwarcia wystawy. Opis wystawianych przedmiotów sporządza sam wystawiający. Opis ten jest następnie poświadczony przez komisarza wystawy lub inny organ pełniący taką rolę.

\subsection{Niemcy}

Szczególnej uwagi wymaga sytuacja prawna w Niemczech, gdzie pierwszeństwo z wystawienia na wystawach krajowych wzorów użytkowych, wzorów przemysłowych i towarów lub usług oznaczonych znakiem towarowym jest popularnym i powszechnym sposobem promowania określonych wystaw i targów.

Niemieckie prawo własności przemysłowej przewiduje w odniesieniu do wzorów użytkowych (Gebrauchsmuster), wzorów przemysłowych (dawniej Geschmacksmuster, obecnie Design) i znaków towarowych (Marken) instytucję pierwszeństwa z wystawienia na: a) oficjalnych lub oficjalnie uznanych wystawach międzynarodowych w rozumieniu Konwencji podpisanej w dniu 22 listopada 1928 r. w Paryżu o wystawach międzynarodowych (amtlichen oder amtlich anerkannten internationalen Ausstellung im Sinne des am 22. November 1928 in Paris unterzeichneten Abkommens über internationale Ausstellungen) lub b) pozostałych wystawach krajowych lub zagranicznych (auf einer sonstigen inländischen oder ausländischen Ausstellung).

W przypadku wystawienia na takiej wystawie wzoru użytkowego, wzoru przemysłowego lub towaru czy usługi oznaczonej znakiem towarowym zgłaszający może powołać się na prawo pierwszeństwa z wystawienia, jeśli dokona zgłoszenia w niemieckim Urzędzie Patentowym w terminie 6 miesięcy od dnia pierwszego wystawienia na wyżej wymienionej wystawie.

Przepisy te znajdują się w $\S$ 6a ust. 3 ustawy o wzorach użytkowych (Gebrauchsmustergesetz (GebrMG), ${ }^{45} \S 15$ ust. 3 ustawy o prawnej ochronie wzorów (Ge-

\footnotetext{
44 Loi du 13 avril 1908 r.elative à la protection temporaire de la propriété industrielle dans les expositions internationales étrangères officielles ou officiellement reconnues, et dans les expositions organisées en France ou dans les territoires d'outre-mer avec l'autorisation de l'administration ou avec son patronage. Ustawa dostępna na stronie : http://www.legifrance.gouv.fr (data dostępu: 14.09.2015 r.). 45 Ustawa dostępna na stronie: http://www.gesetze-im-internet.de/bundesrecht/gebrmg/gesamt.pdf (data dostępu:
14.09.2015 r.), (BGBI. z dnia 28.sierpnia 1986 r., I s. 1455 z późn. zm.).
} 
setz über den rechtlichen Schutz von Design (Designgesetz - DesignG)), ${ }^{46}$ a także w $\S 35$ ust. 3 ustawy o ochronie znaków towarowych i innych oznaczeń (Gesetz über den Schutz von Marken und sonstigen Kennzeichen (Markengesetz - Marken$G)) .{ }^{47}$ We wszystkich powyżej przywołanych niemieckich ustawach przewiduje się, że Ministerstwo Sprawiedliwości i Ochrony Konsumenta (Bundesmisterium der Justiz und Verbraucherschutz) określa katalog wystaw krajowych i zagranicznych, na których wystawca będzie mógł się powołać na pierwszeństwo z wystawienia. ${ }^{48}$ Katalog takich wystaw musi zostać opublikowany w monitorze federalnym (Bundesanzeiger). ${ }^{49}$

W ustawach został nałożony też obowiązek, zarówno w stosunku do wystaw w rozumieniu Konwencji o wystawach międzynarodowych, jak i pozostałych wystaw krajowych i zagranicznych, że ten kto powołuje się na pierwszeństwo z wystawienia, musi wskazać dzień i miejsce wystawy, a także przedstawić dowód z wystawienia (zob. $\S 6$ ust. 4 GebrMG, $\S 15$ ust. 4 DesignG i $\S 35$ ust. 4 MarkenG). Z analizy ogłoszeń organizatorów wystawców wynika, że organizatorzy wystaw w większości przypadków wskazują w informacjach o organizowanych targach i wystawach na możliwość skorzystania przez wystawców w pierwszeństwa wystawienia.

Jak wskazuje się w niemieckiej literaturze przedmiotu ogłoszenie w oficjalnym publikatorze o pierwszeństwie z wystawy ma znaczenie konstytutywne. Komentatorzy zwracają też uwagę na wzrastającą liczbę ogłaszanych wystaw krajowych, jak i zagranicznych. ${ }^{50}$

\section{Uzasadnienie przywrócenia instytucji pierwszeństwa z wystawienia na publicznych wystawach krajowych w p.w.p. i uwagi de lege ferenda}

\subsection{Uzasadnienie wprowadzenia}

Wydaje się więc, że instytucja pierwszeństwa z wystawienia, dotycząca innych wystaw niż wystaw międzynarodowych oficjalnych lub oficjalnie uznanych, jest potrzebna i dopuszczalna. Obecna, polska regulacja pierwszeństwa z wystawienie poza niejasnym statutem wystaw międzynarodowych oficjalnych lub oficjalnie uznanych w sposób oczywisty pomija wszystkie wystawy organizowane w Polsce.

\footnotetext{
46 Ustawa dostępna na stronie: http://www.gesetze-im-internet.de/bundesrecht/geschmmg_2004/gesamt.pdf (data dostępu: 14.09.2015 r.), (BGBI z dnia 24 lutego 2014 r., I s. 122).

47 Ustawa dostępna na stronie: http://www.gesetze-im-internet.de/bundesrecht/markeng/gesamt.pdf (data dostępu: 14.09.2015 r.), (BGBI. z dnia 25 października 1994 r., I s. 3082 z późn. zm.).

48 Dla przykład można przytoczyć treść § 6 ust. 3 GebrMG (zbliżona regulacja jest też w § 15 ust. 3 DesignG i § 35 ust. 3 MarkenG) , którego brzmienie jest następujące =: „Wystawy, o których mowa w ust. 1 numer 1, będą w każdym przypadku ustalone przez Ministerstwo Sprawiedliwości i opublikowane w monitorze federalnym" (Die Ausstellungen nach Absatz 1 Nummer 2 werden im Einzelfall vom Bundesministerium der Justiz bestimmt und im Bundesanzeiger bekanntgemacht).

49 Bekanntmachung über den Ausstellungsschutz z dnia 18 listopada 2014 r. Opublikowane dnia 26 listopada 2014 r. w BAnz AT dnia 26 listopada 2014 B1.

50 Zob. K-H. Fazer, Markenrecht, wyd. 4, Monachium 2009, s. 1951, Nb, 7.
} 
Pierwszeństwo z wystawienia na publicznych wystawach krajowych miałoby przede wszystkim znaczenie dla dwóch grup podmiotów, z jednej strony to organizatorzy wystawy i targów, z drugiej strony wystawcy.

Niewątpliwie pierwszeństwo z wystawienia na publicznych wystawach krajowych ma duże znaczenie marketingowe. Można zauważyć, że zdają sobie z tego sprawę niemieccy organizatorzy wystaw, którzy w informacjach o wystawach i targach bardzo wyraźnie podkreślają, że wystawienie na danej wystawie daje podstawę do ubiegania się o pierwszeństwo z wystawienia. Biorąc pod uwagę, że nie każda wystawa, czy targi dają taką możliwość, czyni to dane targi czy wystawę bardziej atrakcyjną dla wystawców. Nałożenie pewnych wymogów (jak np. przed nowelizacją - rękojmia wiarygodności, ustalona renoma, długoletnia tradycja, organizacja wystawy przez uznaną jednostkę) co do takich wystaw jest zasadne, gdyż podnosi dodatkowo ich znaczenie.

Niewątpliwie przyznanie prawa pierwszeństwa wystawowego podnosi znacznie rangę organizowanej wystawy. Wystawcy mają poprzez priorytet pewność uzyskania praw wyłącznych do przedmiotów własności przemysłowej ujawnianych na wystawie. W okresie priorytetu konkurencyjne zgłoszenia dokonane przez innych przedsiębiorców muszą ustąpić pierwszeństwa przedsiębiorcy biorącemu udział w wystawie, o ile potrafi on wykazać, że wcześniej niż zgłaszający konkurent wystawił przedmiot zasługujący na ochronę przez prawo własności intelektualnej na tej wystawie. Nadaje to wystawie rangi oficjalnie akceptowanej wystawy, na której wystawcy są ,pod opieką” władzy państwowej. Zachęca także wystawców do wystawiania na targach nowych rozwiązań technicznych, estetycznych czy odróżniających bez obawy utraty siły atrakcyjnej i nowości w wyniku wystawienia. Dla organizatorów targów jest to także okazja przyciągnięcia nowości rynkowych i technicznych, które bez zabezpieczonego priorytetu z wystawy nie miałyby szansy pojawienia się na wystawie. O takie nowości tymczasem w znacznej mierze chodzi organizatorom targów i wystaw.

Ponadto przyznanie priorytetu wystawowego targom czy wystawom zwiększa zainteresowanie wystawami ze strony lokalnych środowisk fachowców zajmujących się własnością przemysłową. Targi muszą zatrudniać fachowców - z reguły rzeczników patentowych - wystawiających zaświadczenia uczestnictwa w wystawie czy targach dla celów powoływania się na priorytet $\mathrm{z}$ wystawienia. W toku targów mogą powstać spory o własność intelektualną angażujące często lokalne środowiska radców prawnych, adwokatów lub rzeczników patentowych. Rośnie w ten sposób także pośrednio świadomość znaczenia i roli własności intelektualnej wśród wystawców i zwiedzających. Także organy prokuratury i policji muszą być fachowo przygotowane do ścigania naruszeń praw własności intelektualnej występujących na targach czy wystawach, gdyż często tylko interwencja tych organów w czasie targów czy wystaw daje możliwość stwierdzenia naruszeń praw własności intelektualnej. 
Z powyższych obserwacji wynika, że priorytet wystawowy jest istotnym elementem podnoszącym świadomość roli i znaczenia własności intelektualnej w prowadzeniu działalności gospodarczej zarówno wśród przedsiębiorców, jak i w społeczeństwie w ogólności.

Jednakże podmioty powołujące się na pierwszeństwo $\mathrm{z}$ wystawienia w przypadku proponowanej regulacji muszą mieć na uwadze, że co do zasady pierwszeństwo ograniczałoby się tylko do wystaw na terytorium Polski. Skuteczność w Polsce pierwszeństwa $\mathrm{z}$ wystawienia za granicą na wystawie nie uznanej oficjalnie należałoby badać w indywidualnym przypadku biorąc pod uwagę, że kwestie te regulują przepisy krajowe, a nie przepisy Unii Europejskiej.

Uznać należy też, że przyjęte obecnie przez Polskę regulacje są zgodne z Konwencją paryską, która określa pewne minimum zabezpieczenia pierwszeństwa wystawowego. Wprowadzenie pierwszeństwa $\mathrm{z}$ wystawienia także na publicznych wystawach krajowych nie byłoby jednak sprzeczne z tą Konwencją, ani prawem UE. Dowodzą tego w szczególności rozwiązania niemieckie i francuskie.

\subsection{Uwagi de lege ferenda}

Nowelizacja p.w.p. z 2007 r., na podstawie której uchylono instytucję pierwszeństwa $\mathrm{z}$ wystawienia na polskich wystawach (art. 15 ust. 2-4 i art. 125 ust. 2-4) nie miała wystarczających podstaw w odniesieniu do wzorów użytkowych, wzorów przemysłowych i znaków towarowych. Świadczy o tym zresztą brak jakiegokolwiek uzasadnienia dla wprowadzonych zmian.

Obecnie, w toku prac nad kolejną nowelizacją p.w.p., należałoby poddać pod dyskusję możliwość przywrócenia instytucji pierwszeństwa z wystawienia na polskich wystawach. Przykład innych państw europejskich, a w szczególności Niemiec, daje faktyczne uzasadnienie proponowanej zmianie. Przywrócenie omawianej instytucji może mieć duże znaczenie dla polskich organizatorów wystaw, wystawców, Urzędu Patentowego (ze względu na zwiększoną liczbę zgłoszeń do rejestracji), prawników, a także społeczeństwa w ogólności.

Ewentualnie można by dyskutować, czy to Prezesa Urzędu Patentowego należy obciążać obowiązkiem wskazywania wystaw publicznych w Polsce, podczas których można żądać pierwszeństwa z wystawienia. Może właściwszym byłyby tu inne organy administracji publicznej np. wojewoda? Kwestia ta musi być dokładnie skonsultowana, przede wszystkim z przedstawicielami UPRP, którzy mają w tym zakresie największe doświadczenie zebrane podczas obowiązywania uchylonej regulacji.

Istotną propozycją rozwiązań legislacyjnych byłoby także jasne i wyraźne określenie procedury wskazywania i ogłaszania wystaw, podczas których można by powołać się na pierwszeństwo $\mathrm{z}$ wystawienia. Wskazanym byłoby zaangażowanie specjalistycznych instytucji, które powinny proponować (bądź konsultować) wystawy, które „dają rękojmię jej wiarygodności, w szczególności cieszą się ustaloną renomą, na dhugoletnią tradycję bądź organizowana jest przez uznaną jednostkę zaj- 
mującą się zawodowo organizacją podobnych wystaw". Uznać należy, że klauzule generalne zawarte $\mathrm{w}$ uchylonych przepisach zapewniały elastyczność w wyborze wystawy. Ewentualnaą kwestię ich pominięcia, czy wprowadzenia bardziej precyzyjnych i szczegółowych wymogów trzeba wziąć pod dyskusję z zainteresowanymi podmiotami i instytucjami w toku prac legislacyjnych.

W świetle powyższych uwag można by zaproponować następujące rozwiązania legislacyjne.

„W tekście art. 15 p.w.p. dodaje się ust. 2,3 i 4 :

2. Pierwszeństwo do uzyskania, prawa ochronnego albo prawa $z$ rejestracji przysługuje także, na zasadach określonych w ust. 1, w przypadku wystawienia, wzoru użytkowego albo wzoru przemysłowego na innej niż określona w ust. 1 wystawie publicznej w Polsce, wskazanej przez Prezesa Urzędu Patentowego w formie obwieszczenia w Dzienniku Urzędowym Rzeczypospolitej Polskiej «Monitor Polski».

3. Wskazanie wystawy, o której mowa w ust. 2, może dotyczyć tylko imprezy dającej rękojmię jej wiarygodności, w szczególności jeżeli cieszy się ona ustaloną renomą, ma długoletnią tradycję bądź organizowana jest przez uznaną przez Polską Izbę Przemysłu Targowego jednostkę zajmującą się zawodowo organizacją podobnych wystaw.

4. Z zachowaniem warunków określonych $\mathrm{w}$ ust. 3 , z inicjatywą wskazania wystawy publicznej w Polsce jako dającej pierwszeństwo, o którym mowa w ust. 2, może także wystąpić właściwy minister lub wojewoda".

W tekście art. 125 p.w.p. dodaje się ustęp 2, 3 i 4:

2. Pierwszeństwo do uzyskania prawa ochronnego na znak towarowy przysługuje także na zasadach określonych w ust. 1, według daty wystawienia towaru oznaczonego znakiem towarowym lub świadczenia usługi pod takim znakiem na innej niż określona w ust. 1 wystawie publicznej w Polsce, wskazanej przez Prezesa Urzędu Patentowego w formie obwieszczenia w Dzienniku Urzędowym Rzeczypospolitej Polskiej «Monitor Polski».

3. Wskazanie wystawy, o której mowa w ust. 2, może dotyczyć tylko imprezy dającej rękojmię jej wiarygodności, w szczególności jeżeli cieszy się ona ustaloną renomą, ma długoletnią tradycję bądź jest organizowana przez uznaną przez Polską Izbę Przemysłu Targowego jednostkę zajmującą się zawodowo organizacją podobnych wystaw.

4. Z zachowaniem warunków określonych $\mathrm{w}$ ust. 3, z inicjatywą wskazania wystawy publicznej w Polsce jako dającej pierwszeństwo, o którym mowa w ust. 2, może także wystąpić właściwy minister lub wojewoda". 


\section{IS THERE A NEED TO REINTRODUCE THE EXHIBITION PRIORITY ON THE NATIONAL EXHIBITIONS IN THE POLISH LAW OF INDUSTRIAL PROPERTY?}

Until 2007 the exhibition priority on public national exhibitions organized in Poland recognized utility models, designs and trademarks in the Polish Law of Industrial Property. An exhibitor who exhibited his products at a public exhibitions organized in Poland, could claim the priority before the Polish Patent Office in the case of registering his intangible goods (such as trademarks, utility models and designs). With the priority certificate so issued, the date of the exhibition counted as the date of submission of the application for registration.

As a result of an amendment in 2007, this form of the exhibition priority has been repealed and nowadays exhibitors cannot claim an exhibition priority on public exhibitions organized in Poland in registering his intangible goods.

In the opinion of the authors the amendment repealing the exhibition priority was not justified. The authors consider that the exhibition priority could be an useful tool not only for exhibitors willing to register their products but also for the Polish organizers of the exhibitions to attract exhibitors, patent attorneys and lawyers. The German Industrial Property law in which the exhibition priority is recognized provides a good example thereof.

Słowa kluczowe: prawo własności przemysłowej, pierwszeństwo z wystawienie, wzór użytkowy, wzór przemysłowy, znak towarowy

Keywords: industrial property law, exhibition priority, utility models, design, trademark 